\title{
Oxford professor faces business link inquiry
}

\section{London}

Both Oxford University and the Wellcome Trust are investigating the business affairs of Roy Anderson, the suspended zoology professor and Wellcome Trust governor.

The inquiries are in response to concerns raised during a separate inquiry into Anderson's behaviour in connection with the appointment of a faculty member in the department (see Nature403, 472, 353;2000).

The investigations are believed to include Anderson's involvement with the company International Biomedical and Health Sciences Consortium (IBHSC), an Oxfordbased biomedical consultancy. Anderson is one of the directors, and holds one-third of its shares.

Anderson is a governor of the Trust, a director of the Wellcome Trust Centre for the Epidemiology of Infectious Diseases, and a respected scientist and a government adviser known for his pioneering work on AIDS and on the spread of BSE among British cattle.

He is currently suspended from Oxford University and his position as director of the Centre, while the inquiry into the faculty appointment is underway. Both Oxford and the Wellcome Trust emphasize that their inquiries are neutral, and make no presumption of innocence or guilt.

The Trust and the university will cooperate on the new inquiry on matters of mutual interest. The Trust says that its inquiry will be completed in weeks rather than months, and has promised that there will be "no attempt to hide anything".

One of the Trust's guiding principles is that the research it funds is charitable and not constrained by any organization or grant holder's commercial interests. For example, Trust-funded researchers may not consult for a commercial organization in which they hold a significant equity interest, unless the consultancy relates to an area outside the Trust's interests.

The Trust generally defines a significant

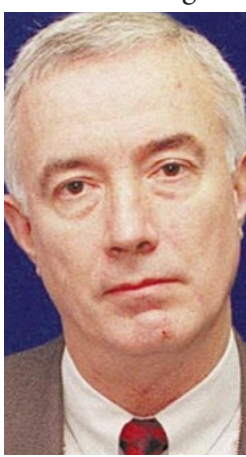
equity interest as more than 5 per cent of the organization's outstanding equity interest. Its rules add that, in some circumstances and at the discretion of the Trust, researchers may hold more than this after obtaining prior written agreement.

Anderson and Jack

Anderson: owns one- Crew, a business conthird of consultancy. sultant, are directors of IBHSC, which is based

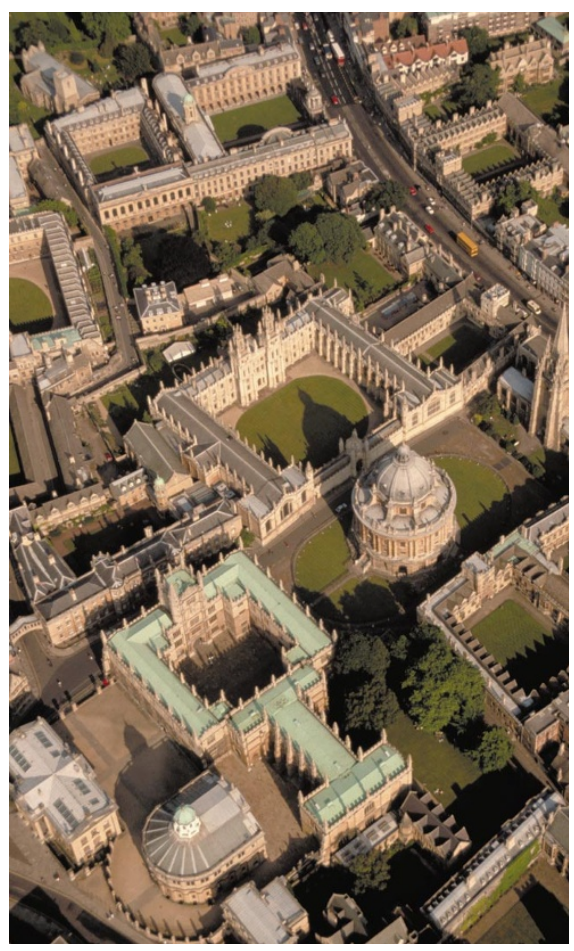

Oxford University is carrying out "inquiries within the Wellcome Trust Centre".

at the Oxford Science Park. IBHSC has client pharmaceutical companies in Europe and the United States, with contracts to work on the use, delivery, epidemiology and economics of anti-infectives and vaccines. A number of scientists from the Wellcome Trust Centre carry out contract work for IBHSC.

Mike Dexter, the director of the Wellcome Trust, has declined to confirm or deny that the Trust has agreed to Anderson's IBHSC activities. Asked whether Anderson's involvement with IBHSC was in line with Wellcome Trust rules, he also declined to comment. Dexter added: "Obviously we take any issues raised seriously but we must carry out due process."

In response to a question from Nature about the continued tenability of Anderson's position as governor, given the new investigation, the Trust said in a statement this week that it is "carrying out inquiries into the concerns raised by yourself and others. As these are currently underway it would be inappropriate for us to comment. We do not want to prejudge any issues."

Oxford University also confirmed last week that it is examining the links between Anderson, his company IBHSC and the drug company Abbott Laboratories. A spokesperson said "I can't say too much about this business other than to reassure you it has been drawn to our attention and will be investigated."

Later, an official statement said that the university was carrying out "inquiries within the Wellcome Trust Centre in accordance with our standard practices. It would be inappropriate to prejudge the outcome of these inquiries in any way."

IBHSC was incorporated on 3 October 1997; accounts from this date up to $31 \mathrm{March}$ 1999 show that IBHSC held $£ 1.1$ million cash at the bank and in hand. Anderson and Crew each hold exactly a third of the equity of IBHSC; the other shareholder is Camrep Investements SA, in County Cork, Ireland. Efforts to locate the address of the company or contact either it or its registered offices have been unsuccessful.

As well as being a governor of the Trust, Anderson is the principal applicant on three current Wellcome Trust awards valued at

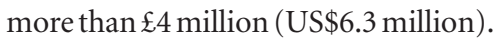

The inquiries will be embarrassing for both the Trust and the Centre, which has acknowledged academic links with Abbott Laboratories. A recent paper on antigen-driven $\mathrm{CD}^{+}{ }^{+} \mathrm{T}$ cell and HIV-1 dynamics (Proc. Natl Acad. Sci. USA 96, 15167-15172; 1999), co-authored by researchers from the Centre, acknowledges Abbott for "advice and access to pharmacological data”.

Abbott is a world leader in anti-infective research. Their innovations include the antibiotic Biaxin and Norvir (Ritonavir), an HIV protease inhibitor.

Anderson's Wellcome Trust grants are for the Centre's core funding, research into the population and evolutionary biology of infectious diseases, and a supercomputer for investigating the persistence, dynamics and control of human and animal infectious diseases.

In recent years, the Trust has expressed concern over the huge amount of work and responsibility Anderson has taken on, including work as a governor and director of the Centre.

This is said to have led to an attempt to persuade him to step down as a governor which failed after Anderson's lawyers objected on his behalf — and to Anderson's decision last year not to take up the position of biological secretary of the Royal Society to which he had been elected.

Last week Anderson's lawyers said that they would respond "vigorously and quickly" to any suggestion of wrongdoing on Anderson's part. They declined a request for an interview with Anderson. In the past week Crew was also unavailable for interview, despite previously agreeing to be interviewed.

Abbott Laboratories were asked about their involvement with IBHSC and the Centre, but were unable to respond before Nature went to press.

Natasha Loder 